\title{
Efficacy of Bacterial Collagenase Therapy in RFM Cows Assessed through Endometrial Biopsy
}

\author{
P. Mohan ${ }^{1 *}$, K. Krishnakumar ${ }^{2}$, K. Kulasekar ${ }^{3}$, S.M.K. Karthickeyan ${ }^{4}$ and \\ M. Murugan ${ }^{5}$
}

${ }^{1}$ Department of Veterinary Gynaecology and Obstetrics, Veterinary College, Shivamogga 577 204, KVAFSU, Karnataka, India

${ }^{2}$ Cattle and Buffalo Breeding Unit, Post Graduate Research Institute in Animal Sciences, Kattupakkam-603203, Tamil Nadu Veterinary and Animal Sciences University, T.N., India ${ }^{3}$ Department of Veterinary Gynaecology and Obstetrics, ${ }^{4}$ Department of Animal Breeding Genetics, Madras Veterinary College, Vepery-600 007, Tamil Nadu Veterinary and Animal Sciences University, T.N., India

${ }^{5}$ VUTRC, Melmaruvathur, Tamil Nadu Veterinary and Animal Sciences University, T.N., India

*Corresponding author

\begin{tabular}{|l|}
\hline Ke y w o r d s \\
Uterine tissue \\
biopsy, RFM, \\
Bacterial \\
collagenase \\
response, Cows
\end{tabular}

\section{Keywords}

Uterine tissue biopsy, RFM,

Bacterial

Article Info

Accepted:

10 August 2018

\section{A B S T R A C T}

The study was conducted in cases of RFM presented within 12 to 24 hours after parturition to Obstetrics Unit of Madras Veterinary College, Chennai. Group I received placebo treatment with one litre of normal saline intravenously. Group II cows, treated with intrauterine proteolytic bolus containing nitrofurazone, metronidazole and urea and antibiotic therapy (Inj. Streptopenicillin @ 20,000 units/kg body weight) without manual removal for 7 days. Groups III cows, received single dose of 2, 00,000 CDU of collagenase plus $40 \mathrm{mg}$ of calcium chloride and 40 $\mathrm{mg}$ of sodium bicarbonate dissolved in one litre of normal saline at a $\mathrm{pH}$ of 7.5 intravenously through jugular vein (Eiler and Hopkins,1993). Group IV received single dose of $2,00,000 \mathrm{U}$ of collagenase intravenously. The endometrial histopathology findings on day 14 and 35 in group I revealed mild to moderate glandular activity with haemorrhage and vascular activity, hyperplasic changes in the mucosa and infiltration of mononuclear cells. The higher degree of focal necrosis of epithelial mucosa and infiltration of neutrophils were recorded in group II and IV than group I and III; group II had severe fibrotic necrosis than group IV. Group II had severe diffused cellular infiltration and increased inflammatory response. Group III had mild to moderate glandular activity, infiltration of bacterial colonies, mild necrotic tissues, neutrophilic and lymphocytic infiltration; group IV had higher leucocytic infiltration, bacterial load and focal necrosis than group III. These histopathological results were revealed that the administration of collagenase through intravenous route had achieved better healing and recovery. 


\section{Introduction}

If the placenta is retained longer than 8 to 12 $\mathrm{h}$, it is considered pathological and referred as retention of foetal membrane (Hanafi et al., 2011). The incidence of retained foetal membrane (RFM) varies from 4 to16 per cent in cattle (Hossein and Ardalam, 2011), which leads to reduced milk yield, endometritis and poor fertility.

A variety of methods have been used in the treatment of RFM, which includes manual removal and / or administration of oxytocin, $\mathrm{PGF}_{2 \alpha}$, antibiotics, immunomodulators etc., although the efficacy of these treatments are questionable (Eiler, 1997). The alternate route for the collagenase administration instead of umbilical arteries was reported by Eiler and Hopkins (1993) that the dose of $2.2 \times 106 \mathrm{U}$ in $1000 \mathrm{ml}$ physiological saline solution over a period of $30 \mathrm{mts}$ through jugular vein. The collagenase administration through umbilical artery is the effective treatment for RFM in dairy cows; however, such collagenase treatment is costly and administration through the umbilical cord is more difficult after $48 \mathrm{hrs}$. Hence, the study was formulated to determine the effect of collagenase through intravenous route instead of umbilical arteries. Further, the efficacy of different treatment regimens was studied and the healing processes were assessed through the uterine biopsy with histopathological study of endometrial tissue (Chapwanya et al., 2010).

\section{Materials and Methods}

Fifty two healthy and parous cows less than 10 years of age, presented to the Large Animal Obstetrics Unit, Teaching Veterinary Clinical Complex, Madras Veterinary College, Chennai-7 were utilized for the study. Seven healthy cows with normal calving and shedding of placenta were served as group I (control) and treated with one litre of normal saline intravenously. Thirty cows with unassisted calving followed by retained foetal membranes between 12 and $24 \mathrm{~h}$ interval were selected and randomly allotted into groups II and III of fifteen each. Fifteen cows with difficulty in parturition followed by RFM were considered as group IV.

Group II cows, treated with intrauterine proteolytic bolus containing nitrofurazone, metronidazole and urea and antibiotic therapy (Inj. Streptopenicillin @ 20,000 units/kg body weight) for 7 days without manual removal. Groups III and IV cows, received single dose of 2, 00,000 CDU of collagenase plus $40 \mathrm{mg}$ of calcium chloride and $40 \mathrm{mg}$ of sodium bicarbonate dissolved in one litre of normal saline at a $\mathrm{pH}$ of 7.5 intravenously through jugular vein (Eiler and Hopkins, 1993).

Uterine endometrial biopsy samples were collected in vivo using Albuchin's uterine biopsy catheter on day 14 and 35 postpartum in all the groups. The collected tissue samples were trimmed, dehydrated, cleared and embedded in paraffin section at a thickness of 5 to $6 \mu$ and stained with haematoxycilin and eosin for histological examination as per the procedure described by Balasubramanian (1994) and Karunakaran et al., (2012).

\section{Results and Discussion}

On day 14 and 35 postpartum, group I cows had mild to moderate glandular activity with haemorrhage and vascular activity, hyperplasic changes in the mucosa, and infiltration of mononuclear cells than the remaining groups (Plate 1). These findings were in concurrence with the observations of Dolatkhah et al., (2013) who reported that the number of endometrial blood vessels, necrotic regions, and endometrial neutrophilic infiltrations were slightly increased in the endometritic cows than healthy cows on days 27 to 79 postpartum. Similar reports were 
made by Bonnett et al., (1991) that the single columnar epithelium lining the endometrium of the uterus is denuded, allowing invading bacteria access to the underlying stromal compartment immediately after parturition. These mild inflammatory changes in the endometrium, such as focal areas of cellular infiltration have little effect on fertility (DeBois and Manspeaker, 1989) in group I cows.

The higher degree of focal necrosis of epithelial mucosa and infiltration of neutrophils were recorded in groups II and IV than groups I and III on days 14 and 35; however, group II had severe fibrotic necrosis than group IV (Plate 2, 3 and 4). These findings were in agreement with the observations of Singh et al., (1987) and McEntee (1990) that the different degrees of periglandular fibrosis were produced by intrauterine infusions of iodine solutions due to inflammatory changes in dairy cows. Chronic signs of inflammation such as dilatation of endometrial glands and periglandular fibrosis leading to delayed involution (DeBois and Manspeaker, 1989) might be the reason in group II for the prolonged lochial discharge and delayed involution.

Group II had severe diffused cellular infiltration and increased inflammatory response due to severe irritation caused by the administration of intrauterine proteolytic drugs than the remaining groups. These results concurred with the observations of Raja et al., (2012) who reported that cows with severe infection had characteristic changes in endometrium like glandular hyperplasia with periglandular fibrosis and necrotic changes with cystic dilatation which indicated poor fertility. These results revealed that the cows with RFM treated by an irritant intrauterine drugs causes uterine damage, which concurred with the observations of Schnyder et al.,
(1990) that irritant drugs like Lugol's iodine solution locally showed severe changes of degeneration and cellular infiltration in endometrial tissues, which led to reduced fertility. Further, the delayed involution in group II might be related to disruption of endometrial epithelium, infiltration and accumulations of inflammatory cells, vascular congestion and stromal edema (Polat et al., 2015).

Group III had mild to moderate glandular activity, infiltration of bacterial colonies, mild necrotic tissues, neutrophilic and lymphocytic infiltration on days 14 and 35 postpartum, which was comparable with the results of group I. Though the group IV received collagenase administration, had higher leucocytic infiltration, bacterial load and focal necrosis than group III on days 14 and 35 postpartum. These findings were in agreement with the observations of Sheldon et al., (2009) that the bacterial infection caused by the trauma, which disrupted the endometrial tissue structure and function. The tissue damage occurred while handling dystocia leading to inflammation, which favours elevated bacterial load (Herath et al., 2009; Cronin et al., 2012) might delay the collagenolysis efficiency, even with the exogenous administration of collagenase in group IV, this result in delayed uterine involution.

The higher degree of focal necrosis of epithelial mucosa and infiltration of neutrophils were recorded in group II and IV on day 14 and 35; however, group II had severe fibrotic necrosis with diffused cellular infiltration and increased inflammatory response than group IV. In group III had mild to moderate glandular activity, infiltration of bacterial colonies, mild necrotic tissues, neutrophilic and lymphocytic infiltration on day 14 and 35 postpartum. Group IV had higher leucocytic infiltration, bacterial load and focal necrosis. 
Plate 1. Histopathology of uterine endometrium in Group I cows

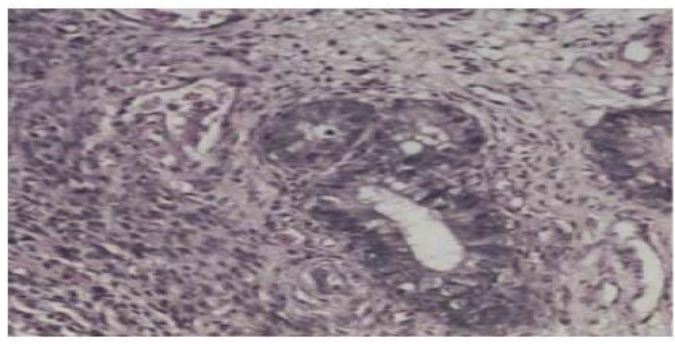

Day 14: Moderate glandular activity

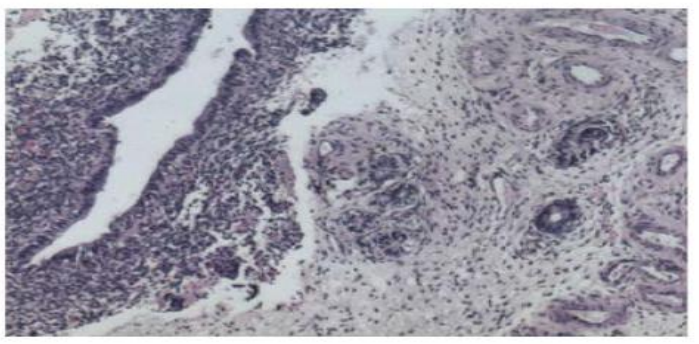

Day 35: Mild glandular activity, fibroblast, an infiltration mononuclear cells, heavy neutrophilic infiltration, bacterial colonies and necrotic tissue

Plate 2. Histopathology of uterine endometrium in Group II cows

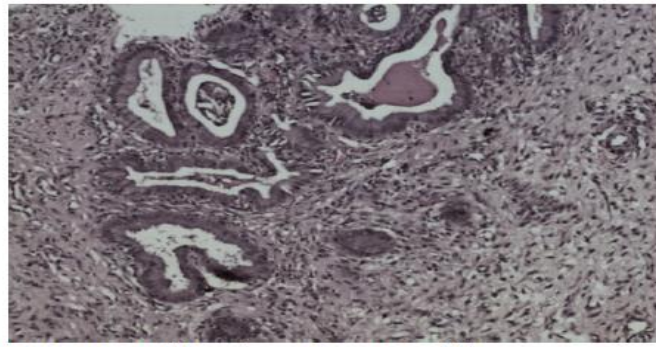

Day 14: Infiltration of neutrophils and lymphoplasmacytes

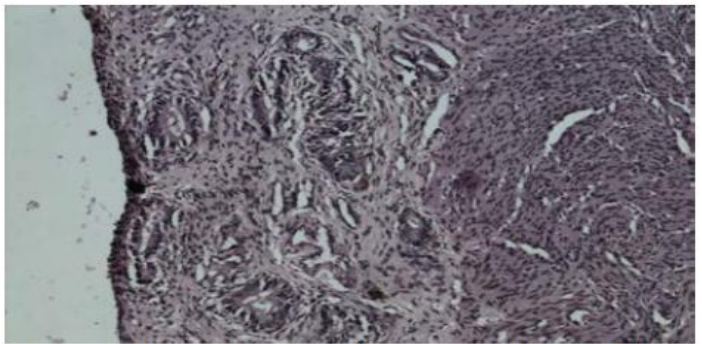

Day 35: Increased vascular activity, mild fibrosis and mild lymphocytes and focal necrosis

Plate 3.Histopathology of uterine endometrium in Group III cows

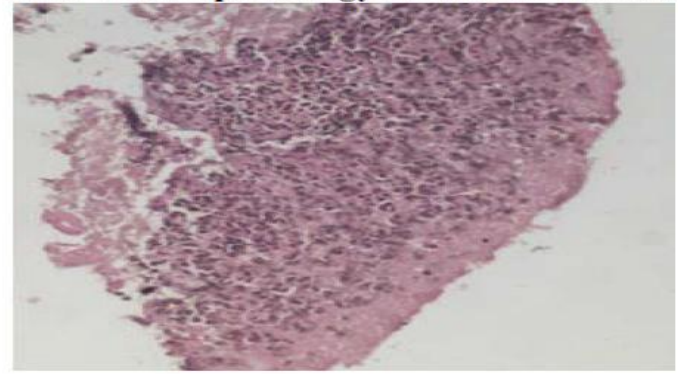

Day 14: Heavy neutrophil infiltration, bacterial colonies and necrotic tissues

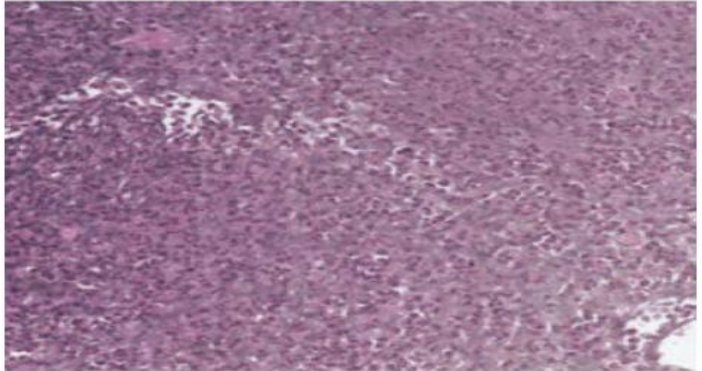

Day 35: Heavy neutrophil infiltration, sub mucosal mononuclear cells infiltration and bacterial colonies

Plate 4. Histopathology of uterine endometrium in Group IV cows

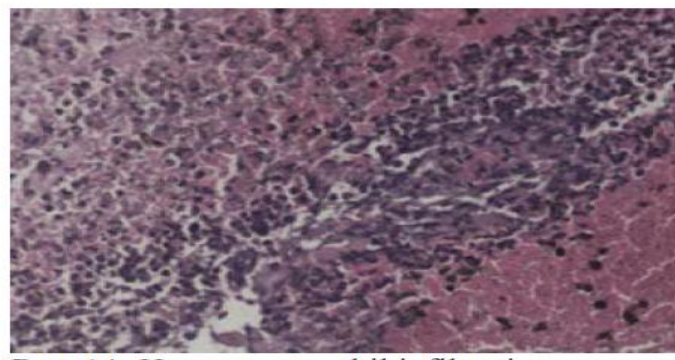

Day 14: Heavy neutrophil infiltration and necrotic tissue

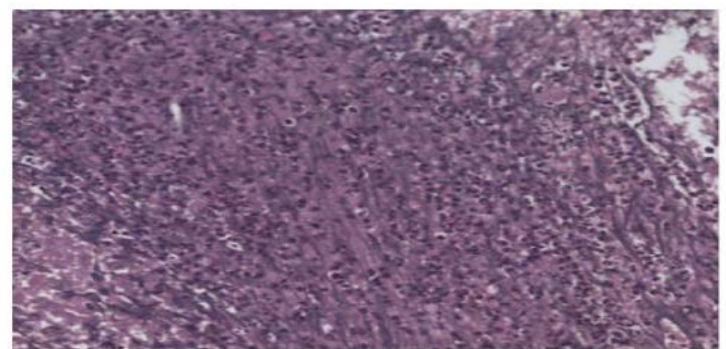

Day 35: Heavy neutrophilic infiltration 
These results showed that the administration of single dose of 2, 00,000 CDU of collagenase plus $40 \mathrm{mg}$ of calcium chloride and $40 \mathrm{mg}$ of sodium bicarbonate dissolved in one litre of normal saline at a $\mathrm{pH}$ of 7.5 intravenously through jugular vein is recommended for the treatment of RFM than the other intrauterine therapy.

\section{Acknowledgement}

The authors thank the Department of clinics, Madras Veterinary College, Vepery, Chennai and TANUVAS for the necessary support and funding to carry out the research work.

\section{References}

Balasubramanian, S (1994). Studies on retained foetal membranes in buffaloes. Ph.D., Thesis. Submitted to Tamil Nadu Veterinary and Animal Sciences University, Chennai.

Bonnett, B. N., S. W. Martin, V. P. J. Gannon, R. B. Miller and W. G. Etherington (1991). Endometrial biopsy in Holstein-Friesian dairy cows. III. Bacteriological analysis and correlations with histological findings. Can. J. Vet. Res., 55: 168-173.

Chapwanya, A., K. G. Meade, F. Nariciandi, P. Stanley, J. F. Mee, M. L. Doherty, J. J. Callanan and C. O'Farrelly (2010). Endometrial biopsy a valuable clinical and research tools in bovine reproduction. Theriogenology, 73: 988994.

Cronin, J. G., M. L. Turner, L. Goetze, C. E. Bryant, I. M. Sheldon (2012). Toll-like receptor 4 and MYD88 - dependent signaling mechanisms of the innate immune system are essential for the response to lipopolysaccharide by epithelial and stromal cells of the bovine endometrium. Biol. Reprod., 86: 51- 59 .
DeBois, C. H. W and J. E. Manspeaker (1989). Endometrial biopsy of the bovine: Diagnosis, treatment and prevention of reproductive diseases in animals. Current Therapy in Theriogenology, $2^{\text {nd }}$ Edn., W. B. Saunders, Philadelphia, Pp. 424-426.

Dolatkhah, B., A. H. Mahdavi, H. R. Rahmani, M. A. Edriss, M. Khorvash (2013). Cytologic and histological characteristics of endometritis in postpartum dairy cows. Annals. Biol. Res., 4: 70-76.

Eiler, H (1997). Retained placenta. In: Current therapy in large Animal Theriogenology. W.B. Sounders Company, Philadelphia, Pp. 340-348.

Eiler, H and F. M. Hopkins (1993). Successful treatment of retained placenta with umbilical cord injections of collagenase in cows. J. Am. Vet. Med. Assoc., 203: 436-443.

Hanafi, E. M., W. M. Ahmed, H. H. E. L. Khadrawy and M. M. Zabal (2011). An overview on placental retention in farm animals. Middle East J. Sci. Res., 7: 643-651.

Herath, S., S. T. Lilly, D. P. Fischer, E. J. Williams, H. Dobson, C.E. Bryant and I. M. Sheldon (2009). Bacterial lipopolysaccharide induces an endocrine switch from PGF2 $\alpha$ to PGE2 in bovine endometrium. Endocrinology, 150: 1912-1920.

Hossein, N.G and M. Ardalam (2011).Cowspecific risk factors for retained placenta, metritis and clinical mastitis in Holstein cows. Vet. Res. Commun., 35: 345-354.

Karunakaran, M., E. B. Chakurkar, P. K. Naik, B. K. Swain and N. P. Singh (2012).Endometritis in dairy cow's causes and management. Extension folder Number - 48/2012. Prepared by ICAR Research Complex, Old Goa, 403 402. 
McEntee, K (1990). Reproductive pathology of domestic mammals. Academic Press, $1^{\text {st }}$ Edn., San Diego, Pp. $167-168$.

Polat,B., M. Cengiz, O. Cannazik, A. Colak, E. Oruc, S. Altun, S. Salar and A. Bastanc (2015). Endometrial echo texture variables in postpartum cows with subclinical endometritis. Anim. Reprod. Sci., 155: 50-55.

Raja, S., T. G. Devanathan, K. Kulasekar, N. Pazhanivel and C. Balachandran (2012). Whiteside test and endometrial biopsy for diagnosis of endometritis in repeat breeding cows. Indian J. Anim. Reprod., 33: 56 - 58.

Schnyder, D., U. Kupfer and R. Zwahlen (1990).Changes in the endometrium of the cow after intrauterine administration of different drugs. Schweiz Arch. Tierheilkd, 132: 353-364.

Sheldon, I, M., J. Cronin, L. Goetze, G. Donofrio and H. J. Schuberth (2009). Mini Review: Defining postpartum uterine disease and the mechanisms of infection and immunity in the female reproductive tract in cattle. Biol. Reprod., 81: 1025-1032.

Singh, C.V., R. C. Gupta, D. N. Sharma and A. K. Sinha (1987). Histomorphological and cytological studies on the endometrial glands of repeat breeding cows treated with lugol's iodine and oxytetracycline. The Indian J. Anim. Sci., 57: 891-894.

\section{How to cite this article:}

Mohan, P., K. Krishnakumar, K. Kulasekar, S.M.K. Karthickeyan and Murugan, M. 2018. Efficacy of Bacterial Collagenase Therapy in RFM Cows Assessed through Endometrial Biopsy. Int.J.Curr.Microbiol.App.Sci. 7(08): 4058-4063. doi: https://doi.org/10.20546/ijcmas.2018.708.421 